\title{
Review Aritice
}

\section{Falsafah Science of Fritjof Capra in Handling the Environment Destruction}

\author{
Jefirstson Richset Riwukore', Fellyanus Habaora ${ }^{2,}$, Yohanes Susanto ${ }^{2}$, Asnath Maria Fuah ${ }^{3}$, \\ Rudi Priyanto $^{3}$, Luki Abdullah ${ }^{3}$, Ahmad Yani ${ }^{3}$, Bagus Priyo Purwanto ${ }^{3}$ \\ ${ }^{1}$ Management Graduate Program, Indo Global Mandiri University, Palembang, Indonesia \\ ${ }^{2}$ Programme Animal Production and Technology, Faculty of Animal Sciences, Bogor Agricultural University, Bogor, Indonesia \\ ${ }^{3}$ Animal Production and Technology, Faculty of Animal Sciences, Bogor Agricultural University, Bogor, Indonesia
}

\author{
Email address: \\ habaorafhomas@yahoo.co.id (F. Habaora) \\ ${ }^{*}$ Corresponding author
}

\section{To cite this article:}

Jefirstson Richset Riwukore, Fellyanus Habaora, Yohanes Susanto, Asnath Maria Fuah, Rudi Priyanto, Luki Abdullah, Ahmad Yani, Bagus Priyo Purwanto. Falsafah Science of Fritjof Capra in Handling the Environment Destruction. American Journal of Engineering and Technology Management. Vol. 5, No. 6, 2020, pp. 103-115. doi: 10.11648/j.ajetm.20200506.13

Received: July 14, 2020; Accepted: August 5, 2020; Published: December 31, 2020

\begin{abstract}
Fritjof Capra introduces a new vision in seeing the reality through the discovery of holistic ecological truth that is linear in nature with the basics of holistic ontology pluralist-spiritualistic-organism and a basis epistemological of synthesis, interactive dialogue, and subject equality. Based on this, Capra explained that the balance between science and technology that is limited by moral values and religion will create ecological sustainability by itself, while the capitalist, materialistic, and hedonism perspective of humanity overrides spiritualism only as a pseudo science. This causes Capra's world view to appear in various fields as the wisdom of nature which is described as the ability of the planet's ecological ecosystems to organizing themselves in complex ways. This is seeing in the perspective of Capra, a science for sustainbale living which explained that science for the sustainability of life no need to create sustainable human society from zero, but can mimic natural ecosystems which are plant communities, animals and microorganisms that are sustainable. This condition explains that when there is a balance between the use of science and technology which is limited by aspects of conscience and religion (Yang) then sustainability automatically occurs. But due to the different perspectives that further increase environmental damage such as climate change, Capra offers the concept of ecoliteracy that guarantees a solid continuation of life together on planet Earth, namely: networks, cycles, solar energy, partnerships, diversity, and balance dynamic. Therefore, Capra offers a solution for solving climate change is eco-literacy which he calls spreading to various fields of science because it will develop into an ecodesign. The groups expected to understand ecoliteration in the face of environmental change (climate change) are politicians, business leaders, professionals at all levels, and educational institutions. This group, according to Capra, is a group of public or institutional policy makers and trusted input providers who have the real ability to create community impacts far ahead.
\end{abstract}

Keywords: Sustainability, Ecoliteracy, Climate Change

\section{Introduction}

The relationship between science and mysticism that was initiated by Fritjof Capra gave rise to its own charm for the world. Fritjof Capra courage to go out of the box from the scope paradigm scientific of positivistic, empirical and rational to a paradigm of spiritual, metaphysical, and moral become paradigm (world view) Capra that holistic-pluralist-spiritualistic-organism spread to various fields of science. Capra brings together the two poles of the world (West and East) which have always been disputed. Fritjof Capra is a pure scientist who began his academic career by exploring theoretical physics. Then Capra broadened its intellectual horizons by studying the insights of Eastern mysticism. Through one of his works, The Tao of Physics (1975), then introducing new interpretations of quantum 
physics theory and relativity theory using Eastern mysticism which is reinterpreted holistically. The interpretation of quantum physics is then systematically deepened by building an ecosystemic paradigm in the next work The Turning Point (1982). This ecosystemic paradigm is then refined into a more general paradigm by introducing complex systems in his work The Web of Life (1996). In addition to the three works, Capra also wrote other works such as Uncommon Wisdom (1988) and The Hidden Connections (2002) which helped strengthen his ideas about Eastern wisdom in modern science.

Generally, the unification between modern science and Eastern mysticism seems impossible because the domains of the two fields are diametrically different. From an ontological point of view, science views reality as something that is empirical, calculative, and verification. Meanwhile, mysticism views reality as something that is metaphysical, intuitive, and speculative. Bringing these two perspectives together in a field of scientific study means simultaneously positioning concrete and abstract reality in the same area. Capra introduces a new vision in seeing reality and apparently able to penetrate the dividing wall between modern science on the one side and mysticism on the other. In addition, he also managed to overcome the crisis of perception that shackles the human mind since a few centuries ago. Capra also succeeded in offering an alternative paradigm that can be used as capital in building the future of human civilization.

The worldview of ecological/holistic introduced by Fritjof Capra in 1986 is now beginning to spread to various fields (health, psychology, sociology, etc.) especially about the way he views the environment. Thus the purpose of this review is to (1) find out what is meant by Capra with A Science for Sustainable Living; (2) find out what is meant by ecological literacy by Capra; and (3) knowing Capra's views on climate change and what Capra has to offer.

\section{Research Methodology}

This research used a descriptive method which was analyzed quantitatively and qualitatively. The information source used is secondary data, namely from scientific journals, magazines, and so on. Work procedures are carried out by dissecting information from reliable reference sources, which can be traced to the Google Scholar Index, to identify relevant academic literature. In addition, this study analyzes the various perspectives of Fritjof Capra used by researchers. This scientific research was carried out for 3 (two) months, namely June-August 2019. The process of preparing reports was carried out by referring to the stages of research, namely data collection, data reduction, data presentation, and conclusion drawing.

\section{Results and Discussion}

\subsection{Worldview: The Concept of Ecological Sustainability from Fritjof Capra}

The crisis of modern humans globally makes humans the cause of ecological crises that occur in three forms of environmental damage, namely (1) global warming, (2) depletion of the ozone layer, and (3) acid rain. Fritjof Capra [7] through books and/or videos circulating on Youtube regarding "The Turning of Point" explains "... for the first time we are faced with the threat of the extinction of the real human race and all life forms on this planet". Furthermore, it is stated that the real reality of all these threats is so close to humans through air pollution that threatens lung health, water pollution that triggers disease, deforestation that threatens floods and landslides, technology and industrialization that triggers global warming, and so forth. This shows the complexity of the problem to be addressed globally, both technical and non-technical (ethics-morals, scientific metaphysics, depth, local wisdom, religious wisdom, and the wisdom of the great traditions of the world). The threat of extinction of the human race called Fritjof Capra turned out not to be a hypothesis but a reality, which appears in the statement of the United States Vice President of the 1993-2001 period, Albert Arnold Gore Jr., stated that the history of the extinction of human civilization due to climate change triggered by environmental crises such as Mayan civilization (now Yucatan, Mexico) in $950 \mathrm{M}$ as a result of loss of soil fertility, water crisis, and deforestation. Likewise, the disaster that befell the Chinese nation in the form of repeated flooding in the Yellow River in 1332 which killed seven million people caused by climate change. Even Thamrin [41] states that the picture of the extinction of civilization in human history is very likely to be repeated today, where the scope of the crisis can be broader and deeper because technology can enlarge the extent of destruction if the humanity that sustains it keeps separating between scientific facts and values axiology. Furthermore, it is suggested that interdependent awareness (holistic ecology) of all human beings can put the brakes on the rate of environmental crises that bring about the extinction of the earth's environment [26-28].

The statement of the Vice President of the United States during Bill Clinton reign, and the thoughts put forward by Thamrin [41] is thought to be the adoption of Fritjof Capra thought that the environmental crisis as a mirror of the spiritual, moral, and local wisdom (culture) which is the basic basis of global thoughts holistically-comprehensive to contribute to increasingly severe environmental degradation. Environmental crises that occur due to the civilization of knowledge, scientific facts are often separated from cultural values, separating ethics from everyday life, separating subject from object, separating soul from body, separating spirit from matter, and even separating fact from value. Even though all of the supporting components of the environment are a unity. Fritjof Capra view of ecology actually illustrates that sustainability occurs when there is a balance between environmental components such as humans, animals, plants or forests, water, soil, and air are an interdependent and mutually owned holon. If there is a balance between these ecological components, then there is automatically sustainability, so this is not mentioned in Fritjof Capra book "The Turning Point" or according to Capra's recognition in the Youtube video with the title "Living Systems and Leonardo da Vinci (https: 
//www.youtube.com/watch? $\mathrm{v}=19 \mathrm{o} 1 \mathrm{r} 0 \mathrm{~m} 6 \mathrm{IKA})$, or in broad outline depicted ontologically or epistemologically in the video The Turning Point and Sustainability (https://www.youtube.com/watch?v=Oziq1 -xjRpc); and video of Systems Thinking and Sustainability (https://www.youtube.com/watch?v=yDaVdz94kao)". The balance is also according to Capra that in addition to occurring in the relationship between humans and nature (sensory experience), it is also about the relationship between humans and conscience. Thus everything is synthesis and interactive.

The scientific truth of Fritjof Capra in the world view of ecological sustainability occurs when there is a holistic ecological perspective as reported by Rahayu et al. [24] that the values of Sundanese cultural wisdom in the preservation of environmental functions by building a model of empowerment of the religious-cosmic environment based on watersheds based on the conception of Sundanese culture (one of the tribes in Indonesia) has been able to prioritize relations and balance between ecological justice and social justice, more accommodating equality and balance between community welfare and environmental harmony that is seen from human interaction with the environment with an objective picture of Ciomas village community (one of the regions in Bogor Regency, West Java Province, Indonesia) in applying values its ancestral cultural values in the preservation of environmental functions and efforts to implement the values of Sundanese cultural wisdom in the formulation of environmental law development in Indonesia to be more characteristic of Indonesia.

The perspective of Fritjof Capra on ecological sustainability based on holistic ecology that is non-linear in nature is also evident in the results of Saragih et al. [32] research on adult whale hunting as a source of meat for the residents of Lamalera Flores, East Nusa Tenggara (Indonesia) and given traditional sanctions for violations poaching of children who are still aged by traditional institutions. Adult whaling is also regulated according to the season and is not done at any time. This is to ensure the existence of ecological sustainability through regeneration to ensure sustainability. There is even a belief in the people of Lamalera that if the violation is committed by the people of Lamalera it will get a curse from the ruler. This inheritance is still maintained today. But this situation became different when the casuistic in the Boti tribe of South Central Timor Regency, NTT-Indonesia when it was designated by the government as a tourist area. The Boti tribe adheres to the understanding of the balance of nature, where every use of the forest must be made to change the forest type long before the forest products are utilized. However, when the Boti tribe was designated as one of the tourist villages in NTT and the development of infrastructure in the village of Boti, the use of the forest became unmanageable and further increased the illegal logging rates of the Boti forest. Fritjof Capra states that ecological inequality will arise when ecology is only used as an object of exploitation and experimentation for the benefit of humans.

Another example of Rahmawati's research [25] which reported inequality and injustice against women in Bali (one of the provinces in Indonesia), which looked at men (purusa) as having a more privileged position than women (pradana). This is reflected in the implementation of customary law which still does not have gender equality, where this condition is contradictory to the Hindu views that glorify women as supernatural powers, which have an important role in the creation of the universe. Thus patrilineal culture in particular influences the Balinese customs to be a factor in the occurrence of discrimination against women in Bali. Likewise, the results of Susilo study [37] which states that the results of thoughts about justice from each philosopher in their use are appropriate to be applied in one country/region or also not suitable in other regions/countries, because it is very dependent on social strata or order, culture, and survival of a society that has regional/local wisdom values that are different from one another. Capra stated that epistemologically it is very important in ensuring sustainability through a scientific activity that is synthetic and interactive, where one of the strategies is through communication.

Greenes and Shuman op. cit. Sucia and Samadi [33] state that the importance of communication is due to several things, namely: (1) expressing ideas through conversation, writing, demonstration, and portraying visually in different types; (2) understanding and interpreting and evaluating ideas presented in writing or in visual form; (3) constructing, linking various forms of idea representation and their relation; (4) making observations and connections, formulating questions, carrying, and evaluating information; (5) and produce and express persuasive arguments. Van de Walle states the best way to relate to an idea is to try to convey the idea to others. According to Mustiqon communication is a routine activity of every interaction between two more people. Basically, every activity to move ideas or ideas from one party to another, both between humans and the natural surroundings or vice versa, there will be a process of communication (Musfiqon 2016: 16). Communication is a process of choosing and sending symbols in such a way that helps the listener evoke meaning or response from his mind that is similar to his mind similar to those intended by the communicator [27-28].

The development of science and technology makes world civilization always in contact with science. Quality of understanding aspects of life, law, economics, politics, tradition, ethics, and morals to worship is largely determined by the quality of understanding of science and the meaning of values carried by technology [30]. Dalmeri [10] states that the ability to determine and choose something that gives more good than bad in a wide area and a long period of time is only the mastery of science and technology in the multicultural era which is the hope for humans to act based on the values contained in the teachings of his religion that are relevant to the circumstances and conditions that surround them.

Science and technology that is well mastered, will be able to take measurements and considerations against the good, benefits and at the same time against the bad and the dangers. Fritjof Capra may in his holistic ecological perspective state that science is the grammar set by God for humans to communicate with all-natural resources they have. Science 
and technology are the keys that will open the gates of understanding all the rules, nature, behavior of all the contents of nature. Ecological sustainability with an understanding of science and technology according to Capra is described as something that there is harmony between human endeavors with the provisions set by his Lord (conscience-spiritualism and religion). Fritjof Capra states that the crisis of civilization that occurs because humans are more concerned with living systems that are capitalist, materialistic, and hedonism and spiritualism (inspiration and revelation) are only considered pseudoscience (false science) whose truth is not recognized. The balance between science and technology that is limited by moral values and religion will create sustainability by itself. This is why from Fritjof Capra paradigm began to spread to various fields.

\subsection{The Concept of A Science for Sustainable Living from Fritjof Capra}

A Science for Sustainable Living is a worldview proposed by Fritjof Capra on the use of science and technology to ensure the balance and harmony of civilization, where the balance is created from the influence of holistic-pluralist-spiritualist-organism perspective. This was stated by Fritjof Capra on the diseases of civilization produced by modern humans in a threat to the destruction of civilization. A science for sustainable living is Capra world view to illustrate the epistemological concepts in a group of people who are influential in determining their attitudes and behavior towards nature and the environment. The concept of a science for sustainable living was put forward by Fritjof Capra because the emergence of environmental problems was caused by the worldview that placed human interests at the center of everything in the universe. The value of everything in the universe is seen from mere human interests. This value system is known as anthropocentric or homocentric.

Anthropocentric insight, humans are not part of nature (monism). Humans are the product of God creativity (dualism). Furthermore, humans were created to regulate and conquer nature (pluralistic). The rules that apply to human society do not apply to natural objects or other creatures, such as animals and plants. Thus the anthropocentric perspective gives rise to the dualism between humans on the one side and the universe and other creatures on the other. The conclusion is that the anthropocentric view makes the environment more damaged.

Fritjof Capra then tried to integrate the development of science in physics, biology, and chemistry within the framework of a systematic view of reality. Capra concept that the holistic-ecological paradigm must make the basis of human life to maintain its survival, "A science for sustainable living". The concept of Capra is more real because the ideas it expresses are problems faced directly by the world community, such as the problems of industrialization, the global economic system, global politics. Capra stated that this problem can only be overcome by leaving the mechanistic paradigm towards a systemic/holistic paradigm. The concept of Capra is a discussion of science and spirituality with the main objective of how the concept of reality has an ecological vision.

The Capra concept of "A science for sustainable living" arises when the discovery of the truth of Capra from the escape of the natural sciences or physics and mathematics led by Nicolas Copernicus (1473-1543), Versalinus (1514-1565) and Issac Newton (1642-1727) separating science from its philosophical values. This development is increasingly definitive when Auguste Comte (1798-1857) with the concept of grand theory that the development of human thinking and society will peak at a positive stage, after going beyond the theological and metaphysical stages. The term positive here means that what is true and real must be concrete, exact, accurate, and beneficial [43]. Seeing such developments, then science in the West tends to move away from a variety of knowledge which according to his world is considered to be concrete, not measurable and speculative. On that basis, not only philosophy becomes unattractive in the eyes of science because of its speculative character, but also religious knowledge that is considered out of date and even ahistorical tends to be ignored. It is in this aspect that the development of science creates a different perception of Western society from the moment when its paradigmatic foundations are implanted [21].

Entering the 20th century, the "revolution" of science in the West is still ongoing. Various discoveries have overhauled previously established theories, but these developments have not yet shifted the paradigm of the differentiation or "de-religionism" of science which has been the main characteristic of the progress of the modern era. Indeed, on the one side, such a modern Western ethos and perspective has fostered optimism about science in improving living facilities, but on the other side, the pessimism of the negative impact it causes is also increasingly apparent. Not only has this pessimism haunted its consumers, but especially Western society itself as its main producer.

But in the last half of the 20th century, the ethos of science with such a perspective began to be confronted with new tendencies that paid more attention to the spiritual world. John Naisbitt and Patricia Aburdence, in Megatrend 2000 called it the new age. An era that tries to convince many people that the most appropriate way to solve various personal and social problems that have become part of the crisis of western culture that drives the emergence of New Age will only be resolved if enough people achieve what is called the higher consciousness. Thus, this reality shows the argument put forward by Amin Abdullah that modernism with its very strict differentiation in various fields of life is arguably no longer in line with the spirit of the times.

The observations of Naisbitt and Patricia above have relevance to the views of Fritjof Capra who said that to get out of the shackles of dichotomy in their lives, modern humans are required to be able to integrate values and meanings combined with scientific knowledge and technology. Related to this problem, according to Azizan Baharuddin, there is only one subject that can teach and offer these values, namely religion. Maybe this is not too much because religion is indeed a source of meaning and values that are considered important and can 
be translated through development.

This integrative view is caused by positivistic modern science which tends to reduce the reality of nature, including humans as living things. For example, when talking about cosmology, science always releases it from its spiritual elements such as God, spirit angels and so on [11]. The universe is understood as occurring on its own and governed by a natural law that is independent, permanent and cannot be changed by forces outside of itself. Likewise about humans, which are often seen as religion and philosophy have sublime dimensions such as soul, heart, spirit and so on, perceptions of science are only physical or biological creatures with a very complex nervous system but do not produce the soul as an immaterial substance. In this aspect, humans become devoid of features, as given by philosophy, as a microcosm; or by religion as God representative on earth [16, 22, 29, 33-36, 39].

Based on this, Mehdi Golshani assessment of the neglect of scientific limitations and the denial of the role of philosophy and religion in science is a naive understanding. He also said that science cannot be separated from values completely, much scientific work is filled with philosophical and religious predictions, and metaphysics plays a very important role in almost all levels of scientific activity. Strictly speaking, he considers it too simple to think that philosophical and ideological commitments will never enter into the structure of science (Golshani 2003).

Chandra [9], The theory of the four main elements Jabir bin Hayyan who adopted Greek thought, is actually not acceptable in modern chemistry because basically it is proven later that water, air, and land can be separated again into its constituent elements. But the theory of these four main elements can last for centuries, until later Robert Boyle and Antoinne Laurent Lavoisier (1774) brought it down, and marked the start of modern chemistry entirely on its consistent experimental pathway (Poedjiadji). Meanwhile, Jabir view states that the elements also have a spiritual dimension, although difficult to prove experimentally, it seems that in the development of contemporary science will now be explored again philosophically. As to were in the fields of physics and biology, the philosophical currents of science then show the existence of backflow to enter the immaterial dimension that has been separated from science (Capra the turning of point).

While other Capra concepts for example: Green Politics (1984), a book that tries to analyze the origin of the emergence of a green party in Germany. Uncommon Wisdom (1988) book consisting of Fritjof Capra's conversations with thinkers while writing the book The Turning Point. Belongin to the Universe (1991), a book that tries to explain various parallels between new thinking in science and Christian thought. Ecomanegment (1993), a book written with Ernest Callenbach, writing that attempts to propose an environmentally conscious management. Steering Business Toward Sustainability (1995), a book compiled with Gunter Pauli, this book is a collection of essays written by business, economists and environmental experts who try to outline a variety of practical approaches to moving towards ecological sustainability in business and society, including in media and education.
The direction of philosophical thinking that tends towards secular life not only results in the abandonment of religion, but there are radical consequences, even to the point of doubting the existence of God. The most obvious indication is reflected in Friedrich Nietzsche statement, that at least in the Western world "God is dead" (Capra 1985). This phenomenon, if not immediately realized, will in time give birth to a world without God and without religion. Therefore, at least religion is only placed as a private matter. Therefore, it is not surprising that philosophy and religion in the West each stand alone and develop according to the basis and direction of their own thinking. This process of differentiation, then, is followed by the abandonment of philosophy by the branch sciences who each methodologically, develop their own specialization intensely.

In the field of physics and biology, there is a current to incorporate aspects of immunity and even Eastern mysticism into the study of the philosophy of science, which was pioneered by Fritjof Capra. They then offer a new paradigm in seeing science, with what they call a holistic paradigm. In series, for example, Capra wrote the turning point, the web of life, and the tao of physics to reassert the importance of re-entering the immaterial aspects in the philosophy of science.

The key to an operational definition of ecological sustainability is the awareness that humans do not need to create sustainable human societies from early, but can emulate natural ecosystems, which are sustainable communities of plants, animals, and microorganisms. Because the prominent feature of the earth's household is its inherent ability to support life. Then a sustainable society is a society that is designed in such a way that its way of life, business, economy, physical structure, and technology does not interfere with the inherent ability of nature to support life. Sustainable societies shape their life patterns through continuous evolution with other living systems, human and non-human. Sustainability does not mean that things do not change, sustainability is a process of dynamic coevolution, and not a static state.

\subsection{Worldview Ecological Literacy from Fritjof Capra}

Diamond (2007) op.cit. Widianarko [44] states that historical records show that many ancient civilizations were uprooted due to environmental damage and exploitation of natural resources. Some ancient civilizations that suffered a similar fate, including the Maya Indians in Central America, Greater Zimbabwe in Africa and Angkor Wat in Cambodia. In environmental literature, it is known as ecological suicide. At present there are 12 categories of ecological suicides, namely: (1) logging and habitat destruction, (2) land damage (erosion, salinization, fertility loss), (3) water management, (4) excessive hunting, (5) over-fishing, (6) the impact of introducing new species, (7) population growth, (8) increasing impact per capita of the population, (9) climate change, (10) chemical pollution, (11) lack of energy, and (12) waste of earth's photosynthetic capacity. This underlies Fritjof Capra to drive eco-literacy (environmental literacy) has urged to be immediately promoted among humans (in every aspect of life). 
The word "eco-literacy" is a combination of two words, namely ecological and literacy. Ecological is an adjective which in the understanding of Capra needs to be interpreted as related to ecological principles. Specific ecological principles here need to be placed in a new perspective or new paradigm for future development as a shared life on planet Earth. While "literacy" is a noun that in the Wikipedia language dictionary has the meaning of literacy. The word literacy can be interpreted as the situation of someone who has understood or has an understanding of something. Thus, ecoliteration can be interpreted as a situation of literacy, understanding, or having an understanding of the working of ecological principles in a shared life on planet Earth. Fritjof Capra [8] in his article entitled "Sustainable Living, Ecological Literacy and the Breath of Life" published by the Canadian Journal of Environmental Education, states:

"We need to become, as it were, ecologically literate. Being ecologically literate, or 'ecoliterate', means understanding the principles of organization of ecological communities (i.e. ecosystems) and using those principles for creating sustainable human communities. We need to revitalize our communities-including our educational-communities, business communities, and political communities-so that the principles of ecology become manifest in them as principles of education, management, and politics".

Ecoliteration according to Capra is the basic or first stage in the development of sustainable communities. The second stage is what is called ecodesign, which means ecological design. The third or final stage is the formation of sustainable communities. Capra writes:

"... Of course, there are many differences between ecosystem and human communities. There is no self-awareness in ecosystems, no languange, no consciousness, and no culture: and therefore no justice, nor democracy: but also no greed, nor dishonesty. We cannot learn anything about those human values and shortcoming from ecosystems. But what we can learn from them is how to live sustainably. During more than three billion years of evolution. The planet's ecosystems have organized themselves in subtle and complex ways as to maximize sustainability. This wisdom is the essence of ecoliteracy (Capr, The Web of Life 289-290).

Meanwhile, the concept of eco-design can be applied to almost all fields, such as economics (eco-economics), urban development (eco-city), agriculture (eco-farming), management (ecomanagement). An example of the design called Capra in The Hidden Connections is a ZERI (Zero Emissions Research and Initiatives) industrial development plan created by Gunter Pauli in the early 1990s, industrial development plans based on biological metabolism as drafted by Michael Braungart in Germany and William McDonough in the United States, the design of the development of the photocopy machine industry with a recycling unit by the Canon company in Japan and the design of the development of the automobile industry with the FARE (Fiat's Auto Recycling) system by the Fiat company in Europe.

At first, Capra only used the general term, namely ecological awareness. This term is a general term that is widely used by environmental activists. The new concept of ecoliteration emerged associated with new perspectives or new paradigms that Capra and its peers want to fight for through the Center of Ecoliteracy established in 1995. The concept of ecoliteration can be said as a strategy to move the wider community to embrace a new perspective on reality living together on planet Earth and making the necessary updates.

Life together on planet Earth must be seen no longer mechanically but ecologically and systemically. Shared life needs to be seen as a series of living systems that form a wide network. This wide network consists of small networks that are able to regulate themselves because they have an organization. The organization of these networks is, on the one hand, closed within its own boundaries while on the other side, it is open to the continuous flow of energy and mass in the vast network of planet earth. The flow of energy and mass becomes a resource that continuously drives the life together.

Fritjof Capra wants what is called the wisdom of nature which is described as the ability of the planet's ecological ecosystems to organize themselves in complex ways. The way these ecological systems organize themselves has proven to be very reliable for preserving life on planet Earth. There are six ecological principles proposed by Capra as ecoliteration materials because they guarantee the sustainability of shared life on planet Earth, namely networks, cycles, solar energy, partnerships, diversity, and dynamic balance.

The principles of Capra ecoliteration then explained that: (1) Networks, at all natural scales, we find living systems that are in other living systems of networks in networks. Their boundaries are no boundaries, they are boundaries of identity. All living systems communicate with each other and share resources across their boundaries; (2) Cycle. All living organisms must absorb the continuous flow of matter and energy from their environment to survive, and all living organisms continually produce waste. However, an ecosystem does not produce waste, because the waste of one species becomes the food of another species. Thus, the matter continues to revolve through the web of life; (3) Solar energy. Solar energy converted into chemical energy through photosynthesis of green plants drives ecological cycles; (4) Partnership. The exchange of energy and resources in an ecosystem is supported by cooperation that can cross boundaries. Life does not take over this planet through battle, but through cooperation, partnerships and networking; (5) Diversity. Ecosystems achieve stability and resilience through the richness and complexity of their ecological networks. The greater their biodiversity, the more resilient they are; and (6) Dynamic balance. An ecosystem is a flexible network that continuously fluctuates. Its flexibility is the consequence of many feedback circles that keep the system in a state of dynamic equilibrium. None of the variables is maximized, all variables fluctuate around their optimal value (Capra, The Hidden Connections).

Ecoliteracy is people's knowledge about the environment from the facts and their concern for environmentally friendly products [38]. If the community has the knowledge, has an 
attitude and understands the concept of eco-literacy, the community will understand what needs to be done and how the community relates and acts with the ecosystem so that the community can live sustainably as a place for humans to depend. Orr confirmed and revealed that "Ecological literacy, further, implies a broad understanding of how people and societies to each other and to natural systems, and how they might do so sustainably. The ecologically literate person will appreciate something of how social structures, religion, science, politics, technology, patriarchy, culture, agriculture, and human cussedness combine as causes of our predicament. Its goal is not just a comprehension of how the world works, but in the light of that knowledge, a life lived accordingly. The same is true of theology, sociology, political science, and most other subjects that grace the conventional curriculum. Widianarko [44] states that eco-literacy is an understanding, appreciation, and practice of ecological values that are useful in addressing environmental problems. But eco-literacy is different from ecology because the first mentioned is a package from cognition to affection.

Fritjof Capra (2005) views that the environment is a network of interactions, integration, and communication between natural elements and social components (humans). Both form a complex network and complement each other in order to meet their basic needs. Nature needs to eat from nature. Disrupted natural life will result in natural disasters and ultimately have an impact on humanitarian disasters. Landslides and floods, for example, are natural disasters that occur due to the crisis of trees and forests as water absorbers as well as a buffer against the power of the land, but the natural disasters ultimately lead to many casualties and property. Humans who are ecologically literate or eco-literacy do not only understand and appreciate the natural environment (ecosystems) but will respect all aspects of life, because they will always think of everything that happens because it is caused by human actions themselves. Based on this Capra thinking, it can be concluded that eco-literacy has a goal that is not only one aspect but all aspects.

An idea appears not without reason or cause. The spectacular development of science and technology in the 20th century did not always correlate positively with human welfare. Various serious global problems and crises in the current millennium, there are complex and multidimensional crises. Ecological crises, violence, dehumanization, morals, crime, increasingly open social vulnerability, and the threat of hunger and disease that still haunts are problems that are related to one another. Problems of life in the information age have penetrated domestic and personal life. Fritjof Capra called it the diseases of civilization in The Turn Point.

Likewise, in the world of modern agriculture which is very excessive in the use of chemicals such as the widespread use of pesticides, herbicides, synthetic xorgen fertilizers and so on, it has poisoned the earth, killed wildlife and even poisoned crops and disrupted the health of farmers. Agriculture which was originally called agriculture (culture, a way of life of mutual respect, communal reciprocity, and cooperative, open competitive) developed more popularly as agribusiness, a system that imposes corporate tyranny to maximize profits and reduce costs, making farmers / residents local people who used to have self-esteem and were independent then turned into wage labor on their own land. Then, divorce, drug use, depression, psychopaths, schizophrenia and suicide also add to the concerns of scholars. Arnol Toynbee said that there was a huge imbalance between science and technology that developed so rapidly and moral and human wisdom that did not develop at all, if not said even backward.

World experts such as Lynn White, Toynbee and Daisatsu Ikeda concluded that the anthropocentric world view of monotheism religions was the cause of the ecological crisis. The command to dominate nature resulted in the emergence of an approach to nature that was instrumental, not respectful and this then became a fertile field for the development of science and technology that was destructive to the environment.

The relationship between the three poles, namely God, nature and humans must walk in harmony, balance, and harmony. The removal of one of these poles will cause crippling. The removal of the poles of God will cause secularism that exploits nature and results in an environmental crisis. Elimination of the poles of nature will make people poor knowledge and poor civilization. Fritjof Capra's thinking that there is a balance between pluralism, spiritualism, and nature contained in holistic ecological thinking provides the concept of thinking that eco-literacy can be studied are cultural models based on local wisdom.

Culture is a part of human life having an important role in maintaining balance, preservation and ecological care (both natural and social environment). Culture has contributed to creating a system of ideas and ways of behaving humans so that they are sensitive to various environmental conditions (Purwanto 2008). It's just that human rationality that is manifested in technology precisely unwittingly plays a role in the occurrence of ecological crises. The results of Sajogyo's study (2006) show that the green revolution in Indonesia and the industrialization of agriculture (such as fertilizer and tractors) actually creates new problems in the lives of rural communities. This is due to the cultural values of the local people which tend to be irrational from the academic aspect are actually ignored when making social changes and development planning. Thus, the ecological balance in the modernistic era, such as now, needs to be approached with socio-cultural aspects, so that natural life and society are not disturbed and threatened by disasters. Therefore it is important in preserving nature, the socio-cultural aspects that are owned by the community are used as a foothold for sustainable nature.

Herimanto et al. [14] reported the results of an environmental education assessment (eco-literacy) of disaster-prone communities in Tawangmangu Subdistrict, Karangayar, Central Java (one of the provinces in Indonesia) through the local knowledge of the myth of King Boko, symbolized by the punden-punden which is almost in every hamlet that is believed to have 'and which has' and which 'as an ancestor who was considered a village guard. To respect the existence of Danyang, the Dusun community held rituals or 
traditional ceremonies with the aim of rejecting disaster, especially the occurrence of natural disasters. The attitude of the community that still believes in the existence of the myth of King Boko is considered as an effort to prevent natural disasters through clean village activities accompanied by offerings according to myths to Danyang as village watchmen. The existence of nature for the people of Java is part of the power relations that build relationships between individuals [2]. In this case, creating history is never separated from the existence of nature. When nature is turbulent, then the community is culturally also turbulent. The study of disaster-prone areas is always viewed in terms of natural science so that it is free from the context of the community. Therefore, nature and humans have a history of rationality that is able to develop into a way out. Myth is only considered as a lullaby, it turns out to have a philosophy of natural existence which is the foothold of the Tawangmangu community. The myth of the origin of the community as seen in the Myth King Boko in Pancot has many benefits, not only for ecological traditions but also for the formation of character and knowledge systems of society within the framework of ecological concern. Myths like this are indeed worthy of attention and dissemination by the government, teachers, community leaders, and other parties who care about the ecological future of the Indonesian people in particular, and the world in general.

Cultural aspects have significance for the survival of the community as members of the cultural system. Culture is a source of values and rules that are localists that serves as a guardian of the natural balance and social environment of its people (Geertz 1980). Even Fritjof Capra in a hidden connection (2005) once gave a public lecture before rational elites in America during President Bush administration. $\mathrm{He}$ made the American elite aware that the natural environment is always related to the cultural nature of the people. If we as humans are too greedy in exploiting nature, then that means we want to erode the natural world of human culture. The impact, the balance of nature will be disrupted and lead to a terrible humanitarian disaster. The basic assumption built by Capra is that every cell and natural biosphere (water, soil, air, forest, animals, mountains, wind, plants, etc.) is closely related to the human cultural system. In his monumental book The Turning Point [8], Fritjof Capra said that the human world and nature are two entities that have a dynamic and intertwined balance. Healthy communities and individuals, for example, will always be present if their natural environment is healthy and sustainable. Bad air caused by pollution and carbon dioxide, dirty water due to industrial waste, and deforestation due to illegal logging will disrupt our human system (Friedman, 2009).

Thamrin [41] states that Malay (Eastern) society is full of local wisdom values in protecting the environment. In Malay culture, there is a symbiosis between customary values and religion in environmental preservation. In Malay society, it is full of expressions of preserving forests, rivers, flora, fauna, and natural balance. However, these values of wisdom have been neglected, both internally by Malays and structural factors of the policy that do not pay attention to the application of environmental wisdom values in saving the planet we inhabit. The occurrence of environmental degradation today one of the main factors is the anthropocentric view that does not pay attention to local wisdom. Environmental degradation is also caused by the weakening of the role of traditional institutions and the application of environmental wisdom values to preserve the environment.

Suwondo and Pramudana [38] report that concern for the environment has made the demand for environmentally friendly products increase. This has created new environmental ethics and has increased individual awareness to significantly change consumption behavior. This is caused because: (1) ecoliteracy has a positive and significant effect on consumer attitudes, (2) ecoliteracy has a positive and significant effect on willingness to buy environmentally friendly products, (3) attitudes have positive and insignificant effects on willingness to buy environmentally friendly products, (4) mediating variables namely attitudes are assessed to significantly mediate the relationship between ecoliteracy and willingness to buy environmentally friendly products.

Basukiyatno [5] stated that globalization has created modernity into world culture. Modernity is universal, whereas modernization is always local or national content because it is a synthesis of the economic dimension that continues to look for 'new modes of production' with traditional values or 'mores'. The characteristic of modern society is a picture of a perfect society that is highly dominated by rationality, scientific, far from dogmatic and mystical elements. This understanding turns out to tend to exploit nature and give birth to many problems of life disintegration.

There are many ways about how consumers search for knowledge and the evidence shows that consumers seek knowledge by reading product labels. If consumers have knowledge of environmental issues, then their level of awareness will increase and thus will potentially, promote beneficial attitudes towards green products [42].

\subsection{Worldview from Fritjof Capra and Climate Change Solution}

Global warming is the process of increasing the average temperature of the atmosphere, sea, and land of the earth. The average global temperature at the earth's surface has increased by $0,74 \pm 0,18^{\circ} \mathrm{C}\left(1,33 \pm 0,32^{\circ} \mathrm{F}\right)$ over the past hundred years. The Intergovernmental Panel on Climate Change (IPCC) concluded that most of the increase in global average temperatures since the mid-20th century was most likely due to increased concentrations of greenhouse gases due to human activities through the greenhouse effect. This basic conclusion has been presented by at least 30 scientific and academic bodies, including all national science academics from G8 countries [17]. Rising global temperatures are expected to cause other changes such as rising sea levels, increasing intensity of extreme weather phenomena, as well as changes in the amount and pattern of precipitation. Other consequences of global warming are the impact of agricultural output, the 
loss of glaciers, and the extinction of various types of animals.

Climate change is a long process of excess and unsustainable energy consumption by industrialized countries. Since the industrial revolution took place, the global environment has suffered from air pollution and has had a profound impact on the changing situation of the earth. The use of technology in the context of exploitation of nature plays an essential role in influencing the situation. One result is an increase in greenhouse gas (GHG) emissions that are not natural in the earth's atmosphere, they have an impact on heating the earth's temperature which is very dangerous for the majority of the world's population and for the ecosystem. This climate change is an issue related to development, human rights, and justice issues that are developing amid the ecological crisis facing the world community.

Global warming is a series of stages of global climate change (climate change). The process of global warming begins with the phenomenon of the greenhouse effect (greenhouse effect). On earth, the greenhouse effect is produced by certain gases that are few in the atmosphere. In addition, ice, water points, and small particles in the atmosphere also capture heat. Gerald Foley said the role of GHGs had been discussed by scientists for more than 150 years (Folley 1993 op cit).

Global warming does not occur in a short period of time, but gradually. However, the impact has begun now. In a report issued by the 2001 IPCC, it was concluded that:

"Global air temperatures have risen 0, $6^{\circ} \mathrm{C}\left(1^{\circ} \mathrm{F}\right)$ since 1861. The IPCC agrees that warming is mainly caused by human activities that add greenhouse gases to the atmosphere. The IPCC predicts an increase in global average temperatures will increase $1,1^{\circ} \mathrm{C}$ to $6,4^{\circ} \mathrm{C}\left(2,0\right.$ to $\left.11.5^{\circ} \mathrm{F}\right)$ between 1990 and 2100".

Although the concentration of gases in the atmosphere has not increased again since 2010 the climate continues to warm for a certain period due to emissions that have been released previously. As a result, there will be a dramatic climate change. Even though this climate change event has occurred several times throughout the history of the earth, humans will face this problem with a very large population risk (Hansen).

Research carried out by various world institutions and reports submitted, specifically related to climate change, such as UNFCCC, IPCCC, UNEP, UNCED, WCP, as well as environmental organizations such as WWF, Greenpeace, WALHI, show that the temperature of the earth has increased drastically.

Indonesia is recorded as the fastest forest destroyer with an average forest destruction rate of 1.871 million hectares per year ( 2 percent) of the remaining forests. In fact, Walhi noted that the number had reached 3,4 million hectares per year. losses from illegal logging reach 40-65 trillion every year. In 2003, the rate of forest destruction decreased to 3,2 million hectares and in 2005 around 2,4 million hectares. The consequences of exploitation and deforestation resulted in 673 disasters occurring in Indonesia from 1998-2004 and more than $65 \%$ of them are the impact of improper forest management that causes floods, landslides, and forest fires.
Indonesia's coastal and marine areas also continue to experience damage and degradation. The Indonesian Ocean is one of the few coral reef hotspots in Manado Alliance of 2009 in the world that has been damaged. Data from the World Bank regarding environmental conditions in Indonesia shows that:

Currently, around $41 \%$ of coral reefs are severely damaged, $29 \%$ are damaged, $25 \%$ is pretty good, and only $5 \%$ are still in a natural state. Likewise with regard to mangrove areas or mangrove forests. Around 50\% of mangrove forests in Sulawesi have been lost (some of them have changed to shrimp ponds). Some areas also experience pollution. This occurs in areas that are busy with shipping activities (the Straits of Malacca), or waters that intersect with big cities, such as the waters of the bay of Jakarta and Surabaya. Indonesia's marine areas are also vulnerable to illegal fishing. This activity has been carried out by more than 10 foreign countries in the past 15 years and has reduced 30-50\% of the total national potential of capture fisheries each year.

In other sectors, the cycle of world forest fires continues. Indonesia is a country that has intact ancient forest areas spread across Asia, but the region is experiencing a faster destruction rate of around 1,19 million hectares per year than other regions in the world, so it is considered a global problem because is a major contributor to global climate change. According to Hapsoro, Greenpeace Southeast Asia Campaigner, the damage was a result of human exploitation and its massive destruction of peat forests. The Indonesian Ministry of Forestry emphasizes that forests are home to live so that the survival of various species depends on the preservation of forests for a long time.

Although the concentration of gases in the atmosphere has not increased again since 2010 the climate continues to warm for a certain period due to emissions that have been released previously. As a result, there will be a dramatic climate change. Although in fact, this climate change event has occurred several times throughout the history of the earth, humans will face this problem with a very large population risk.

According to Syarial [40] technology is not only a product of creative culture (techno creative) but also a weapon of community empowerment (the weapons of mass empowerment). The technology in question is current technology, which Habermas in 2002 calls convergence technology, centralized technology, technology at hand. The concrete form is the use of hybrid media, media convergence and social media (social networking).

The dynamics of the paradigm emphasize that counseling is a dynamic and sustainable process, which is not only at the practical level but also in the concepts, materials, methods, techniques, facilities and supporting institutions. Conceptually, the development of counseling is also inseparable from the influence of globalization, the rapid advancement of communication and information technology, the development of economic waves, the implications of multi-dimensional crises, the diaphoretic of excesses of environmental change (global warming, climate change), changes in the regional-political economy-regional map and the development 
paradigm dynamics that are mainstreamed in the world. Affirmed Fritjof Capra (2002), In addition to shifting the development paradigm away from anthropocentric towards the system paradigm, the development factor of communication and information technology that has registered the world (the world is flat) also has a very big influence on the extension approach (no formal education) and education generally. Education shifted from formal space to private and community space, call it homeschooling, tele or cyber-schooling, and creative education communities.

According to this philosophy, the modification and innovation of theory and philosophy need not be in the way of discovering, formulating or constructing a completely new theory and philosophy. Philosophical reconstruction can be done by maintaining the continuity of the views of existing philosophies; take and combine the best elements of every philosophy; and reconstructing it back into a philosophy of synthesis. The most important thing is that the values and goals of each philosophy that will be synthesized in view of contributory to the values and goals in a democratic society and culture, a democratic word civilization characterized by social, political, and cultural situations that are there is no division between minority groups, superiority or particular interest groups [6]. In other words that reconstructionism as a philosophy of synthesis is nothing but a philosophy that seeks to integrate the best values or goals of previous philosophies [12].

In the map of thinking about justice, we should learn from philosophers (take the good and leave the bad), by tracing the history of its development that began in the Greek civilization era, continued in the Roman era, in the medieval Aufklarung and modern times dubbed the information age- technology, until now that began to emerge post-modern understanding. Postmodern here, is a philosophical criticism of the world view (world view), epistemology and modern ideologies [3].

Fritjof Capra (2000) states that the progress of science and technology has become the greatest disaster and threat to human civilization. This is indicated by, among others, various chronic diseases that are more appropriate to be called diseases of civilization, social pathology, and social anomalies. He described that experts were no longer able to solve pressing problems in their area of expertise. The economy is incapable of understanding inflation, oncologists are totally confused about the causes of cancer, psychiatrists are confused by schizophrenia, police are powerless to face increasing crime. based on these findings Fritjof Capra (2000) asserts that the paradigm of science and technology must be replaced. The alternative offered is a vision that contains the following elements: (1) an independent environmental ecological community, (2) gender partnership, (3) an alternative, non-capitalist economy that pays attention to the poor and the environment, (4) the ummah- as a world community that guides the principles of tolerance, and (5) leadership based on science, morals and technology.

The character of western culture like this is not a little drawn criticism from various circles, not least from the West itself. Nietzsche in the 1880 s who died in $1890 \mathrm{M}$, as quoted by Ahmad Tafasir in 2006, reminded that Western culture was on the brink of collapse because it was because the west was too deify ratio. The same thing also stated by Fritjof Capra, western culture has been destroyed, the cause is too deify ratio. Fritjof Capra states that at the beginning of the last two decades of the twentieth century, we find ourselves in a serious global crisis, a complex and multidimensional crisis whose aspects touch every aspect of health and livelihoods, environmental quality and social relations, economics, technology, and politics. This crisis is an unprecedented crisis in human history, for the first time we are faced with the threat of the real extinction of the human race and all life forms on this planet.

There was a nuclear weapons production race, which was enough to destroy the entire world several times, and the arms race continued at a rapid pace. In November 1978, while the United States and Unisoviet (formerly) were completing the second round of talks in a strategic nuclear weapons agreement, the Pentagon launched the program, its most ambitious nuclear weapon for two decades; two years later the program culminated in the biggest military explosion in history: a five-year budget for defense of one thousand billion dollars. Since then American bomb factories have been moving at full capacity. At Pantex, a Texas factory that assembles all nuclear weapons owned by the United States, a number of additional workers are employed and are added with second and third work shifts to increase the production of weapons whose destructive power has never been matched.

The cost of this nuclear madness was shocking in 1978. Before the rise in new costs, world military spending was approximately 425 billion dollars. More than one hundred countries, most of them in the third world, are in the arms shopping business; sales of military equipment for both nuclear and conventional war are greater than national income. Meanwhile, over fifteen million people, mostly children, die of starvation every year; five hundred are also seriously malnourished. Forty percent of the world's population has no chance of getting professional health services, but developing countries spend three times more on weapons than on health. Thirty-five percent of all humanity lacks clean drinking water, while half of all scientists are involved in making weapons.

In America, where the complexity of the military industry has become an integral part of the government. The Pentagon, trying to persuade citizens of the world that building more weapons will make the country safer. The reality is just the opposite, the more nuclear weapons mean the more dangers. Over the last few years, there has been an alarming change in US government policy, a tendency to build a nuclear arsenal not intended for retaliation but for the first attack. There is increasing evidence that the first offensive strategy is no longer a military choice but has become central to American defense policy. In such a situation, every new missile will make nuclear war even more possible. Nuclear weapons do not increase security, as the military says. Nuclear weapons will increase the likelihood of damage globally. The United States faced an unparalleled convergence of crises from the start. The family system is also in a state of crisis. Not only 
that, but also the health system, the urban system, the value system, and especially the political system, which has practically lost the people's trust $[13,31]$.

Capra views that climate change is a phenomenon of the modern world that is supported by the sophistication of science and technology by ignoring ethics, aesthetics and natural balance, namely: (1) the development of nuclear weapons, where the threat of nuclear war is the greatest danger faced by humans when this, though not the only one; (2) damage to global ecosystems and the evolution of life, wherein the deterioration of the quality of the natural environment in the form of air, water, food, and ecological crises. Therefore, it is clear that science and technology are very disturbing and damaging to the ecological system which is the hang of human existence; (3) the global economic crisis, whereas a result of this crisis there was a significant increase in the number of crime and violence, so that anxiety, chaos, and inconvenience of life became a fundamental problem for modern humans. Capra stated that the imbalance between the progress of rational knowledge, intellectual power and technological skills on the one hand with the development of wisdom, spirituality, and ethics, on the other side, has led to uncertainty, disorder, and chaos $[15,18]$.

This chaotic and complex situation has led to the birth of a "new scientific paradigm" form proposed by Fritjof Capra through The Tao of Physics, where Capra offers Taoist interpretations which according to him by elaborating the essence and aspirations of science and religion, the definition of science may be formulated relatively easily [4]. Although it has diverse study objects and each has its own peculiarities, such as physics, chemistry, biology, psychology, sociology, and others. It was further stated that science is one way to obtain legitimate knowledge, together with a number of others, so that they can live peacefully side by side with religion. Capra considers that science and mysticism have the same fundamental view of reality, that is organic, so the social and economic structure of modern society which is based on a mechanistic view must be changed in a manner through a cultural revolution. This revolution can be carried out by taking some of the Ying attitudes of Eastern mysticism to supplement the Yang attitudes of Western science [23]. This Capra view arises from the view of quantum-relativistic physics about reality which is essentially organic, parallel to the nontheistic Eastern mystical view of the which also views the fundamental reality as organic. In other words, Capra tries to show the compatibility between new tendencies in modern science, especially new modern physics with its quantum mechanics characterized by time is relative, sees the universe as "interconnected" because the "basic buildings" forming are the same, regarding "principles uncertainty "at the subatomic level and trying to explain phenomena at a smaller level than the atom, such as the discovery of "quarks" as the smallest particles that make up protons and neutrons, has brought changes not only in physics but also in biology, cosmology, chemistry, and philosophy. This causes that human study objects will become subjects in an interactive pattern.

Capra view is the same as Habermas critical theory which has brought a paradigm shift from "philosophy of the subject" to "philosophy of communication", from "philosophy of consciousness" which has been very dominant in modern society since Descartes to "philosophy of language" by focusing on equal dialogue. Habermas argues that in every communication (dialogue) must provide the validity of four claims, namely: (1) understandability, clarity in expressing oneself so that it is understood; (2) truth, the desire to convey something; (3) truthfulness (trustworthiness) in revealing something; (4) rightness, the speech must be in accordance with communication norms. So good communication must consider the clarity, truth, honesty and accuracy and the context of the shared life that Habermas calls the living world. Widianarko [44] states that the ecoliteracy movement (environmental literacy) offered by Fritjof Capra has urged it to be immediately promoted among the people. It is expected that by having sufficient ecoliteracy, the community will carry out environmental leadership that can be reflected in their "environmental defense" activities.

The above is shown after an environmental case is identified, the first obstacle that will emerge is the opportunity obstacle. Disagreements can revolve around whether the problem really exists and how important it is. Even when the case has been agreed as a problem to be solved, consensus about the scope and ways of reaching a solution and the final goal must be reached. Furthermore, if the barrier to agreement has been overcome, the knowledge barrier raises the next question: is there enough evidence and knowledge available about the causes, the process of occurrence, and the impact of the problem? (we may agree that something should be done about a problem, but we may not know what the cause of it is). After the knowledge barrier is overcome, the next question that arises is: do we have the means to solve that problem (We may agree on the problem, know what its cause is, but not have the means to tackle it), this is the technological barrier. At its peak, after the three previous obstacles were overcome, social, economic and political obstacles confronted the resolution of environmental problems (We may know what to do, but failed to do it for some reason, perhaps limited money, social constraint of political will). These last three obstacles are interrelated and are the determining factors (determining factors) in solving environmental problems. In many cases, there is often an overemphasis on social, economic and political factors so that the truth of scientific knowledge has to be sacrificed. As a result, it is clear that environmental interests are defeated by social, economic and political interests - the memorandum beneath the results of fully human creation.

This view of Capra was initiated by Merchant [20] through the conceptual framework of interpreting ecology and producing an ecological revolution from Fritjof Capra on the concept of sustainability (sustainability) of life on this planet, offered by Capra through the concept of ecoliteration, especially solutions in dealing with climate change. Urgency is increasingly felt by people who love the environment to be able to handle the planet's environmental crisis through fundamental and holistic ways. Handling must be done in 
addition to a fundamental and holistic manner must also be as soon as possible. There is no more fundamental, holistic, and fast method except through a reshuffle of perspective or a paradigm shift accompanied by strong political will. Through the concept of ecoliteration that will be improved later on to the design and finally the formation of sustainable communities. Capra tries to offer a paradigm shift in looking at the life of planet Earth and managing it in a more sustainable way. The demands for a paradigm shift have been hinted at by breakthrough findings in various fields of science as mentioned earlier and by new views developed by ecological groups in deep ecology, a radical environmental movement group [1]. To encourage the creation of a broad paradigm shift movement, Capra prefers moderate to radical methods. According to Capra, the moderate way will be more easily accepted, while the radical way is expected to cause more difficulties, obstacles, resistance among the people. The moderate way can be packaged by utilizing the findings of ecological science. Thus, the concept of ecoliteration is the result of a package of moderate approaches containing the principles of survival as developed in ecology.

The groups expected to understand ecoliteracy are politicians, business leaders, professionals at all levels, and educational institutions. It is to these groups that the concept of ecoliteration is mainly offered. The selection of these groups signaled Capra's hopes for the influence that these groups could create in the interests of broader community change towards a new holistic and ecological perspective. They are groups of public or institutional policy makers and trusted input providers who have a real ability to create community impacts far ahead.

In the era of globalization, political, business and professional groups play a very strategic role. They are groups that are fought over between the two big powers that are still at odds with one another in relation to environmental issues. Namely the supporters of global capitalism and the drivers of the global environment [19]. Capra whose view is placed in second position tries to play the role of the bridge. The language developed is a humanitic language with philosophical, scientific and social organization areas. Through the basic concept of web of life and its derivative concepts of ecoliteration and ecodesign, Capra tries to open the horizons of supporters of global capitalism and invites them to redesign their business activities that are also the cause of climate change. To the group, Capra offered what he called ecodesign.

\section{Conclusion}

Fritjof Capra wants what is called the wisdom of nature which is described as the ability of the planet's ecological ecosystems to organize themselves in complex ways. The way these ecological systems organize themselves has proven to be very reliable for preserving life on planet Earth. There are six ecological principles proposed by Capra as ecoliteration materials because they guarantee the sustainability of shared life on planet Earth, namely networks, cycles, solar energy, partnerships, diversity, and dynamic balance. Climate change is a long process of excess and unsustainable energy consumption by industrialized countries. One result is an increase in greenhouse gas (GHG) emissions that are not natural in the earth's atmosphere, then have an impact on heating the earth's temperature which is very dangerous for the majority of the world's population and for the ecosystem. Fritjof Capra stated that the progress of science and technology has become the greatest disaster and threat to human civilization. Fritjof Capra also offers the concept of sustainability (sustainability) of life on this planet, with the concept of ecoliteration, especially solutions to deal with climate change. The groups expected to understand ecoliteracy are politicians, business leaders, professionals at all levels, and educational institutions. It is to these groups that the concept of ecoliteration is mainly offered. The selection of these groups signaled Capra's hopes for the influence that these groups could create in the interests of broader community change towards a new holistic and ecological perspective. These are groups of public or institutional policy makers and trusted input providers who have the real ability to create social impacts far into the future. To the group, Capra offered what he called ecodesign.

\section{References}

[1] Akib M. 2009. Reflections on modern legal thought: an orientation towards a deep ecology paradigm in the study of legal science. Jurnal Hukum Pro Justitia. Vol. 27 (2): 155-167.

[2] Aminah S. 2008. Indigeneity and reproduction of capitalism knowledge in the power network in the third world. Jurnal Masyarakat, Kebudayaan dan Politik. Vol. 21 (4): 336-351.

[3] Aprison W. 2017. Madrasa: The basis of humanistic-religious epistemology. Jurnal Penelitian Pendidikan Islam. Vol. 12 (1): 117-140.

[4] Arifudin I. 2016. Integration of science and religion and their implications for Islamic education. Jurnal Edukasia Islamika. Vol. 1 (1): 161-179.

[5] Basukiyatno. 2006. Peradaban Islam di Tengah Globalisasi. Jurnal Sosial Ekonomi dan Humaniora. Vol. 2 (2): 1-8.

[6] Brameld T. 1965. Education as Power. New York (USA): Holt, Rinehart and Winston.Inc.

[7] Capra F. 1997. Titik Balik Peradaban: Sains, Masyarakat dan Kebangkitan Kebudayaan. Yogyakarta (ID): Bentang Pustaka.

[8] Capra F. 2007. Sustainable Living, Ecological Literacy and the Breath of Life. Canadian Journal of Environmetal Education. Vo. 12: 9-18.

[9] Chandra E. 2012. Filosofi Zat dan Materi Menurut Jabir Bin Hayyan: Aspek Kimiawi dari Studi Filosofis Terhadap Naskah Mukhtâr Rasâ 'il. Jurnal Scientiae Educatia. Vol. 1 (2): 1-26.

[10] Dalmeri. 2015. Contextualization of Scientific and Religious Values in Multicultural Society. Jurnal Walisongo. Vol. 23 (2): $377-400$. 
[11] Darraz MA. 2012. Islamic Eco-Cosmology in Ikhwan al-Safa's View. Indonesian Journal of Islam and Muslim Societies. Vol. 2 (1): 133-161.

[12] Farisi MI. 2013. Kurikulum Rekonstruksionis dan Implikasinya Terhadap Ilmu Pengetahuan Sosial: Analisis Dokumen Kurikulum 2013. Jurnal Paedagogia. Vol. 16 (2): 144-165.

[13] Gumelar MS. 2016. Dekonstruksi Pemikiran Fritjof Capra Dalam Buku "Titik Balik Peradaban". Jurnal Studi Kultural. Vol. 1 (1): 7-11.

[14] Herimanto, Budiati AC, Utami T. 2013. Ecoliteracy Masyarakat Rawan Bencana Melalui Mitos Prabu Boko di Kecamatan Tawangmangu Kabupaten Karangayar Jawa Tengah. Jurnal Forum Ilmu Sosial. Vol. 40 (2): 178-188.

[15] Hidayat S. 2014. Sacred Science vs. Secular Science: Carut Marut Hubungan Agama dan Sains. Jurnal Studi Agama dan Pemikiran Islam. Vol. 8 (1): 87-101.

[16] Kartanegara M. 2003. When Science Meets Philosophy and Religion. Jurnal Relief. Vol. 1 (1): 22-35.

[17] Kodra HSA. 2004. Bumi Makin Panas, Banjir Makin Luas: Menyibak Tragedi Hutan. Bandung (ID): Yayasan Nuansa Cendekia.

[18] Kusmarni Y. 2008. Teori Chaos: Sebuah Keteraturan Dalam Keacakan [Report Research]. Bandung (ID): Universitas Pendidikan Indonesia.

[19] Loedin AA. 2013. Dampak Global Warming Kepada Kesehatan Manusia. In. Begawan Ilmu Pengetahuan. Jakarta (ID): Akademi Ilmu Pengetahuan Indonesia. Hal. 21-34.

[20] Merchant C. 1995. Earthcare, Women and The Environment. New York (USA): Rountledge Press.

[21] Mufid F. 2013. Perkembangan Paradigma Epistemologi Dalam Filsafat Islam. Jurnal Studi Keislaman Ulumuna. Vol. 17 (1): 19-40.

[22] Nasoetion AN. 1999. Pengantar ke Filsafat Sains. Bogor: PT. Pustaka Litera AntarNusa.

[23] Praja JS. 2006. Aliran-Aliran Filsafat dan Etika. Bandung (ID): Yayasan Pengembangan Ilmu Agama dan Humaniora.

[24] Rahayu MIF, Susanto AF, Muliya LS. 2014. Model Pemberdayaan Hukum Lingkungan Religius-Kosmik Sebagai Upaya Pelestarian Fungsi Lingkungan Hidup. Jurnal Hukum Litigasi. Vol. 15 (1): 70-92.

[25] Rahmawati NN. 2016. Perempuan Bali dalam Pergulatan Gender (Kajian Budaya, Tradisi, dan Agama Hindu). Jurnal Studi Kultural. Vol. 1 (1): 63-69.

[26] Riwukore JR, Habaora F. 2019. Perception of farmers on the performance of extensionist in the pasture agroecosystem of Timor Tengah Utara District. Asian Journal of Agricultural Extension, Economics and Sociology (AJAESS). 29 (2): 1-10. Doi: 10.9734/AJAESS/2019/45539.

[27] Riwukore JR, Habaora F. 2019. The concept of strategy for garbage management in the Kupang City, Indonesian. Saudi Journal of Humanities and Social Sciences (SJHSS). 4 (6): 395-400. Doi: 10.21276/sjhss.2019.4.6.1.
[28] Riwukore JR, Habaora F. 2019. Revolutionary concept of garbage handling in Kota Kupang, Indonesia. Journal of Ecological Engineering and Environment Protection (EEEP). 2: 39-47.

[29] Rozak A, Arifin IZ. 2002. Filsafat Umum. Bandung (ID): Gema Media Pusakatama.

[30] Rumadan I. 2013. Judges' interpretation of special minimum criminal provisions in the corruption act. Jurnal Hukum dan Peradilan. Vol. 2 (3): 379-404. ISSN: 2303-3274.

[31] Samiha YT. 2016. Standar Menilai Teori dalam Metode Ilmiah pada Kajian Filsafat Ilmu. Jurnal Studi Islam Medina-Te. Vol. 14 (2): 133-142.

[32] Saragih S, Lassa J, Ramli A. 2007. Kerangka Penghidupan Berkelanjutan. Kerjasama Hivos Southeast Asia Office dan Circle Indonesia.

[33] Sucia AH, Samadi. 2017. Communication Ability dalam Pemecahan Masalah Perubahan Iklim Sesuai Perspektif Gender. Jurnal Pendidikan Lingkungan dan Pembangunan Berkelanjutan. Vol. XVIII (2): 53-63. ISSN: 1411-1829. DOI: http: //doi.org/10.21009/PLPB.182.04.

[34] Suriasumantri JS. 2000. Filsafat Ilmu Sebuah Pengantar Populer. Jakarta (ID): Penerbit Sinar Harapan.

[35] Surajiyo. 2010. Filsafat Ilmu dan Perkembangannya di Indonesia. Jakarta: Bumi Aksara.

[36] Surajiyo. 2012. Ilmu Filsafat Suatu Pengantar. Jakarta: Bumi Aksara.

[37] Susilo AB. 2013. Penegakan Hukum yang Berkeadilan dalam Perspektif Filsafat Hermeneutika Hukum: Suatu Solusi Terhadap Problematikan Penegakan Hukum di Indonesia). Jurnal Hukum dan Peradilan. Vol. 2 (3): 449-469. ISSN: 2303-3274.

[38] Suwondo SPD, Pramudana AS. 2016. Peran Sikap Dalam Memediasi Pengaruh Ecoliteracy Terhadap Kesediaan Untuk Membeli Produk Ramah Lingkungan. Jurnal Manajemen Unud. Vol. 5 (7): 4575-4601. ISSN: 2302-8912.

[39] Syadali A, Mudzakir. 1997. Filsafat Umum. Bandung (ID): Pusaka Setia Press.

[40] Syarial. 2017. Islamisasi Sains dan Penolakan Fazlur Rahman. Jurnal Lentera. Vol. 1 (1): 82-63.

[41] Thamrin H. 2013. Local Wisdom in Environmental Preservation: The Local Wisdom in Environmental Sustainable). Jurnal Kutubkhanah. Vol. 16 (1): 46-59.

[42] Udin NHW. 2016. Perspektif Islam Tentang Resiprositas Hubungan Pelestarian Alam dan Kehidupan Sosial. Jurnal Studi Keislaman. Vol. 2 (2): 355-381.

[43] Quddus A. 2012. Ecotheology Islam: Teologi Konstruktif Atasi Krisis Lingkungan. Jurnal Ulumuna. Vol. 16 (2): 311-347. ISSN: 1411-3457.

[44] Widianarko B. 2011. Barriers to politics, ecoliteracy and environmental leadership. Jurnal Riptek. Vol. 5 (1): 1-5. 